\title{
ANALISA PERBANDINGAN PERHITUNGAN HARGA POKOK PRODUKSI METODE FULL COSTING DENGAN VARIABLE COSTING DALAM MENENTUKAN HARGA JUAL (STUDI KASUS : UD. MONAS BAKERY)
}

\author{
Lena Magdalena ${ }^{1}$, Suwandi ${ }^{2}$, Trisno Martian ${ }^{3}$ \\ Sekolah Tinggi Manajemen Informatika dan Komputer CIC Cirebon \\ J1. Kesambi 202, Kota Cirebon, Jawa Barat. Telp (0231) 220350 \\ e-mail: lena.magdalena@cic.ac.id, suwandi@cic.ac.id, trisnomartian@gmail.com.
}

\begin{abstract}
Abstrak
Perusahaan harus dapat mengambil keputusan yang tepat dalam menentukan harga pokok produksi (HPP), agar laba yang dihasilkan dapat optimal. Pengambilan keputusan ini menyangkut masalah penentuan harga pokok produk yang tepat. Terdapat dua metode dalam membuat harga pokok produksi (HPP), variable costing dan full costing. Dibuatnya aplikasi perhitungan harga pokok produksi berbasis web ini bertujuan untuk untuk mendapatkan laba yang maksimal dengan melakukan perbandingan harga pokok produksi dengan dua metode yang berbeda yaitu metode full costing dan metode variable costing. . Komponen perhitungan harga pokok produksi dengan metode full costing adalah: biaya bahan baku, biaya overhead pabrik, biaya tenaga kerja, biaya overhead pabrik tetap, biaya overhead pabrik variable. Sedangkan komponen perhitungan harga pokok produksi dengan metode variable costing adalah: biaya bahan baku, biaya overhead pabrik, biaya tenaga kerja, dan biaya overhead pabrik variable. Sistem informasi pencatatan harga pokok produksi ini dikembangkan dengan menggunakan bahasa pemograman berbasis web. Hasil implementasi pengembangan aplikasi harga pokok produksi berbasis web ini menunjukkan bahwa metode full costing memiliki nilai harga pokok produksi yang lebih tinggi daripada metode variable costing. Namun, laba yang diperoleh lebih besar menggunakan metode variable costing.
\end{abstract}

Kata Kunci : Aplikasi, HPP, Full Costing, Variable Costing, Laba

\begin{abstract}
In determining cost of goods production (HPP) companies should be able to take the right decisions so that the resulting profit optimally. This decision concerns the issue of the determination of the price of the staple products that are just right. The price of the staple production there are two methods, namely full costing and variable costing. On a system that has been previously created using only one method of full costing method. But now the company wants to use the variable costing method as a method of comparison in calculating cost of goods production and determine the selling price of its products. He made the application of the calculation of cost of goods web-based production aims to do a price comparison of principal production with two different methods, namely full costing method and variable costing method to get the maximum profit. Record-keeping information system cost of goods production is developed using web-based programming language.The results of the implementation of the application development cost of goods production of web-based shows that full costing method has the value of the production cost of goods higher than variable costing method. However, the profit obtained greater method using variable costing.
\end{abstract}

Keywords: System, HPP, Full Costing, Variable Costing, Profit

\section{Pendahuluan}

Perkembangan industri dunia saat ini memunculkan persaingan yang ketat untuk menghasilkan produk yang berkualitas. Perusahaan sebagai salah satu penggerak perekonomian rakyat serta ikut bersaing dalam menghasilkan suatu produk untuk mendapatkan laba. Laba mempunyai peran yang sangat penting karena menyangkut kelangsungan hidup perusahaan. Hal-hal yang berpengaruh terhadap laba perlu mendapat perhatian yang lebih besar, salah satunya faktor yang ikut mempengaruhi besar laba 
adalah harga pokok produksi. Harga pokok produksi (HPP) adalah sejumlah biaya yang terjadi dan dibebankan dalam produksi. Pengertian yang lain dikemukakan oleh harga pokok produksi adalah biayabiaya yang di keluarkan dalam pengolahan bahan baku menjadi sebuah produk.

Dalam menentukan harga pokok produksi perusahaan harus dapat mengambil keputusan yang tepat agar laba yang dihasilkan dapat optimal. Pengambilan keputusan ini menyangkut masalah penentuan harga pokok produk yang tepat. Harga pokok produksi ada dua metode yaitu variable costing dan full costing. Variable costing yaitu biaya bahan baku, biaya tenaga kerja variable, dan Biaya Overhead Pabrik (BOP) variable, sedangkan full costing (BOP) yang dibebankan adalah biaya bahan baku, biaya tenaga kerja langsung, BOP tetap dan BOP variable. Salah satu masalah yang dihadapi manajer perusahaan yaitu penentuan harga jual produk, harga jual sangat erat kaitannya dengan pencapaian laba. Laba dapat diartikan sebagai imbalan atas upaya perusahaan menghasilkan barang dan jasa.

Salah satu Perusahaan industri yang sedang berkembang di kota Cirebon adalah UD. Monas Bakery yang berlokasi di Jalan Jagasatru No 77. UD. Monas Bakery berdiri sejak tahun 1991 yang bergerak dalam usaha memproduksi Roti Tawar. Pemilik dari perusahaan UD. Monas Bakery bernama Yohan Chandra Oey, di dalam UD. Monas Bakery pencatatan harga pokok produksi selama ini belum menggunakan aplikasi khusus. Hal ini dapat menyebabkan terjadinya kesalahan dalam pencatatan yang kurang teliti dan pencatatan yang dihasilkan belum memiliki standar akuntansi. Akibatnya perusahaan sulit mengetahui nilai keuntungan pasti yang didapatkan dari suatu pemesanan produk secara tepat. Perhitungan yang dilakukan selama ini belum menghasilkan harga pokok yang tepat. Hal ini berdampak pada harga jual yang ditawarkan kepada pelanggan. Oleh karena itu perlu adanya pencatatan harga pokok produksi dengan menggunakan metode full costing dan variable costing karena dengan menggunakan metode ini perusahaan akan mengetahui harga pokok produksi yang sesungguhnya. Adapun alasan penulis memilih metode full costing dan variable costing karena ingin mengetahui perbedaan harga pokok produksi kedua metode tersebut sehingga bisa mengetahui berapa laba dan harga jual yang dihasilkan dengan mengunakan kedua metode tersebut.

Berdasarkan uraian dan penjelasan permasalahan mengenai harga pokok produksi di atas, selanjutnya penulis tertarik membuat sistem aplikasi dengan judul "Analisa Perbandingan Perhitungan Harga Pokok Produksi Metode Full Costing dengan Variable Costing dalam Menentukan Harga Jual (Studi Kasus : UD. Monas Bakery)”.

\subsection{Identifikasi Masalah}

Berdasarkan uraian latar belakang masalah, penulis membuat identifikasi masalah sebagai berikut :

1. Bagaimana mengetahui secara detail perhitungan harga pokok produksi yang sebenarnya?

2. Bagaimana kalkulasi harga pokok produksi dengan menggunakan metode full costing?

3. Bagaimana kalkulasi harga pokok produksi dengan menggunakan metode variable costing?

4. Bagaimana perbandingan kalkulasi harga pokok produksi dengan menggunakan metode full costing dan variable costing sehingga dapat menentukan harga jual yang mampu bersaing?

5. Bagaimana pencatatan laporan harga pokok produksi UD Monas Bakery?

\subsection{Batasan Masalah}

Berdasarkan latar belakang dan identifikasi masalah yang telah diuraikan, batasan masalah dalam penulisan ini adalah sebagai berikut:

1. Pengguna aplikasi ini adalah:

a. Manajer

Manajer bertugas mengelola, biaya bahan baku, biaya tenaga kerja langsung, biaya overhead perusahaan tetap, biaya overhead perusahaan variable produksi. kemudian menggelola data tersebut menjadi laporan harga pokok produksi, laporan analisa perbandingan, dan jurnal umum.

b. Pemilik

Pemilik bertugas melihat dan mencetak laporan harga pokok produksi dan laporan analisa perbandingan harga jual.

2. Prosedur yang membentuk sistem adalah prosedur perhitungan harga pokok produksi, prosedur pencatatan produksi dan prosedur laporan. Dalam sistem tidak membahas hal-hal sebagai

Analisa Perbandingan Perhitungan Harga Pokok Produksi Metode Full Costing dengan Variable Costing dalam Menentukan Harga Jual (Studi Kasus : UD. Monas Bakery)-( Lena Magdalena, Suwandi, 
berikut : prosedur order produksi, prosedur permintaan dan pengeluaran bahan baku, dan prosedur retur barang.

3. Batasan sistem :

a. Sumber informasi berasal dari perkiraan pemilik berupa catatan perkiraan harga pemilik yang belum menggunakan aplikasi khusus.

b. Untuk perhitungan pada aplikasi yang dibuat hanya menghitung jumlah gaji per produksi.

c. Metode analisis yang digunakan adalah metode full costing dan variable costing dengan data sumber perhitungan : biaya produksi, biaya tenaga kerja, biaya penyusutan dan biaya overhead pabrik, tetapi tidak termasuk dengan PPN.

d. Laporan yang dihasilkan adalah jurnal umum, laporan harga pokok produksi dan laporan analisa perbandingan.

e. Sistem ini tidak membahas laporan yang berkaitan dengan laba rugi yang didapat perusahaan.

4. Sumber data Input yang yang digunakan kedua metode tersebut yaitu:

a. Metode Full Costing

Biaya Bahan baku, Biaya tenaga kerja langsung, Biaya Overhead pabrik tetap, Biaya overhead pabrik variable

b. Metode Variable Costing

Biaya bahan baku, Biaya tenaga kerja langsung, Biaya Overhead variabel Sehingga menghasilkan output (Laporan Harga Pokok Produksi dengan menggunakan motode Full Costing dan Variable Costing, Harga Jual Produk, laba, dan laporan analisa).

\subsection{Tujuan}

Tujuan dari penelitian ini adalah sebagai berikut:

1. Mengetahui secara detail harga pokok produksi yang sebenarnya dengan metode full costing dan variable costing.

2. Mengetahui kalkulasi harga pokok produksi yang dijual dengan menggunakan metode full costing.

3. Mengetahui kalkulasi harga pokok produksi yang dijual dengan menggunakan metode variable costing.

4. Mengetahui ada atau tidaknya perbedaan perhitungan harga pokok produksi dalam menentukan harga jual antara metode full costing dengan metode variable costing.

5. Mengetahui pencatatan laporan harga pokok produksi UD Monas Bakery.

\section{Kajian Pustaka}

\subsection{Pengertian Sistem}

Sistem pada dasarnya adalah sekelompok unsur yang erat berhubungan satu dengan lainnya, yang berfungsi bersama-sama untuk mencapai tujuan tertentu (Mulyadi, 2016).

\subsection{Informasi}

Informasi adalah data yang telah diorganisasi, dan telah memiliki kegunaan dan manfaat. Dengan demikian dapat pula disimpulkan bahwa data adalah input bagi sebuah sistem informasi, sedangkan informasi merupakan output. Data diproses menjadi informasi yang bermanfaat bagi para pembuat keputusan untuk menghasilkan keputusan yang lebih baik. Aturan umum yang berlaku adalah, semakin tinggi kualitas informasi yang tersedia bagi para pembuat keputusan, semakin baik keputusan yang dihasilkan (Krismiaji, 2015).

\subsection{Sistem Informasi}

Sistem informasi adalah cara-cara yang diorganisasi untuk mengumpulkan, memasukkan, dan menggolah serta menyimpan data, dan cara-cara yang diorganisasi untuk menyimpan, mengelola, mengendalikan, dan melaporkan informasi sedemikian rupa sehingga sebuah organisasi dapat mencapai tujuan yang telah ditetapkan (Krismiaji, 2015).

\subsection{Harga Pokok Produksi}

Pengertian Harga Pokok Produksi menurut mulyadi yaitu : biaya produksi merupakan biayabiaya yang dikeluarkan dalam pengolahan bahan baku menjadi produk. (Mulyasi, 2016).

Analisa Perbandingan Perhitungan Harga Pokok Produksi Metode Full Costing dengan Variable Costing dalam Menentukan Harga Jual (Studi Kasus : UD. Monas Bakery)-( Lena Magdalena, Suwandi, 


\subsection{Perhitungan Harga Pokok Produksi}

Perhitungan harga pokok produksi adalah untuk mengetahui besarnya biaya produksi yang dikeluarkan untuk memproduksi suatu barang. Pada umumnya biaya produksi tersebut meliputi biaya bahan baku, biaya tenaga kerja langsung, dan overhead pabrik.

\section{a. Biaya Bahan Baku}

Bahan baku merupakan bahan yang membentuk bagian menyeluruh produk jadi.bahan baku yang diolah dalam perusahaan manufaktur dapat diperoleh dari pembelian local, impor, atau dari pengoahan sendiri (Mulyadi, 2014).

\section{b. Biaya Tenaga Kerja}

Biaya tenaga kerja adalah usaha fisik atau mental yang dikeluarkan karyawan untuk mengolah produk. Biaya tenaga kerja adalah harga yang dibebankan untuk penggunaan tenaga kerja manusia tersebut.

\section{c. Biaya Overhead Pabrik}

Biaya overhead pabrik adalah biaya produksi selain biaya bahan baku dan biaya tenaga kerja langsung. Biaya-biaya produksi yang termaksuk dalam biaya-biaya produksi yang termaksut dalam biaya overhead pabrik dikelompokan menjadi beberapa golongan berikut ini:
a) Biaya bahan penolong
b) Biaya reparasi dan pemeliharaan
c) Biaya tenaga kerja tidak langsung
d) Biaya yang timbul sebagai akibat penilaian terhadap aktiva tetap
e) Biaya yang timbul sebagai akibat berlalunya waktu
f) Biaya overhead pabrik lain yang secara langsung memerlukan pengeluaran tunai.

\section{Analisa dan Perancangan}

\subsection{Analisis Sistem yang Berjalan}

Analisa pada sistem yang berjalan dilakukan agar dapat memahami kendala-kendala pada perusahaan tersebut, terkait dengan penerapan sistem baru. Sistem baru yang diusulkan nantinya diharapkan akan mampu memenuhi kebutuhan dari perusahaan tersebut. Analisa sistem yang berjalan dilakukan dengan hal-hal berikut ini:

Analisa perhitungan harga pokok produksi yang sedang berjalan

Adapun biaya yang diperlukan untuk memproduksi roti tawar menurut perusahaan adalah sebagai berikut :

1. Biaya Bahan Baku

Biaya bahan baku meliputi : terigu,margarine,ragi,air,susu,gula

pasir,garam,kalsium dan plastik.

Tabel 1 Biaya Bahan Baku per roti per 2017

\begin{tabular}{|l|c|c|r|}
\hline $\begin{array}{c}\text { Jenis } \\
\text { Bahan } \\
\text { Baku }\end{array}$ & Jumlah & Satuan & $\begin{array}{c}\text { Total Biaya } \\
(\text { Rp) }\end{array}$ \\
\hline \multicolumn{4}{|c|}{ Bahan Baku } \\
\hline Terigu & 0,13 & Ons & 2.000 \\
\hline Margarine & 0,33 & Ons & 400 \\
\hline Ragi & 0,13 & Ons & 200 \\
\hline Air & 0,26 & Liter & 33 \\
\hline Susu & 1 & Bungkus & 67 \\
\hline \multicolumn{5}{|c|}{ Bahan Baku Penolong } \\
\hline Gula Pasir & 0,33 & Ons & 367 \\
\hline Garam & 0,33 & Ons & 67 \\
\hline Kalsium & 1 & Bungkus & 133 \\
\hline Plastik & 0,06 & Ons & 200 \\
\hline \multicolumn{5}{|c|}{ Total } & $\mathbf{3 6 7}$ \\
\hline
\end{tabular}

Analisa Perbandingan Perhitungan Harga Pokok Produksi Metode Full Costing dengan Variable Costing dalam Menentukan Harga Jual (Studi Kasus : UD. Monas Bakery)-( Lena Magdalena, Suwandi, 
2. Biaya Tenaga Kerja

biaya tenaga kerja adalah orang memproduksi roti tawar di UD Monas Bakery.

Tabel 2 Biaya Tenaga Kerja Langsung per roti per 2017

\begin{tabular}{|l|c|r|}
\hline \multicolumn{1}{|c|}{ Bagian } & $\begin{array}{c}\text { Jumlah } \\
\text { Pekerja } \\
\text { (Orang) }\end{array}$ & Total \\
& Biaya Gaji \\
\hline Pemotongan & 2 & 267 \\
\hline Packing & 1 & 133 \\
\hline Pembakaran & 2 & 267 \\
\hline Adonan & 1 & 133 \\
\hline Totak BTKL & $\mathbf{6}$ & $\mathbf{8 0 0}$ \\
\hline
\end{tabular}

3. Biaya Overhead Pabrik

biaya overhead pabrik adalah biaya yang digunakan dalam pembuatan roti tawar di UD Monas Bakery.

Tabel 3.Biaya Overhead Pabrik per Produksi per 2017
\begin{tabular}{|l|r|}
\hline \multicolumn{1}{|c|}{ Keterangan } & $\begin{array}{c}\text { Biaya } \\
\text { (Rp) }\end{array}$ \\
\hline Biaya Listrik & 250 \\
\hline Biaya selotip pembungkus & 26 \\
\hline Total BOP Variabel & $\mathbf{2 7 6}$ \\
\hline $\begin{array}{l}\text { Biaya Penyusutan Gas (sekali } \\
\text { produksi) }\end{array}$ & 86 \\
\hline Total BOP Tetap & $\mathbf{8 6}$ \\
\hline
\end{tabular}

4. Harga Pokok Produksi

Harga Pokok Produksi adalah jumlah total biaya bahan baku, biaya tenaga kerja, biaya overhead pabrik variabel dan tetap.

Dari komponen-komponen di atas dibuat suatu perhitungan harga jual roti tawar menurut UD MONAS Bakery.

Biaya Produksi :

Biaya Bahan Baku

Biaya Tenaga Kerja Langsung

Biaya Overhead Pabrik (T) + (V)

Total Harga Pokok Produksi

$$
\begin{array}{lr}
\text { Rp. } & 3.467 \\
\text { Rp. } & 800 \\
\text { Rp. } & 362+ \\
\hline \text { Rp. } & \mathbf{4 . 6 2 9}
\end{array}
$$

Laba yang diharapkan ( $20 \%$ x Rp 4.629)

Rp $\quad 925$

Harga jual

$=\quad$ Biaya Produksi $+(\%$ Mark Up x Biaya Produksi $)$

$$
\begin{array}{ll}
= & R p 4.629+(20 \% \times 4.629) \\
= & R p 4.629+925
\end{array}
$$

$=\quad \operatorname{Rp} 5.554$ per produk menjadi 5.500

Analisa Perbandingan Perhitungan Harga Pokok Produksi Metode Full Costing dengan Variable Costing dalam Menentukan Harga Jual (Studi Kasus : UD. Monas Bakery)-( Lena Magdalena, Suwandi, 
Jadi Harga Jual Per roti Dalam Perhitungan Pemilik Monas Bakery adalah Rp 5.500

\subsection{Flowchart Sistem Berjalan}

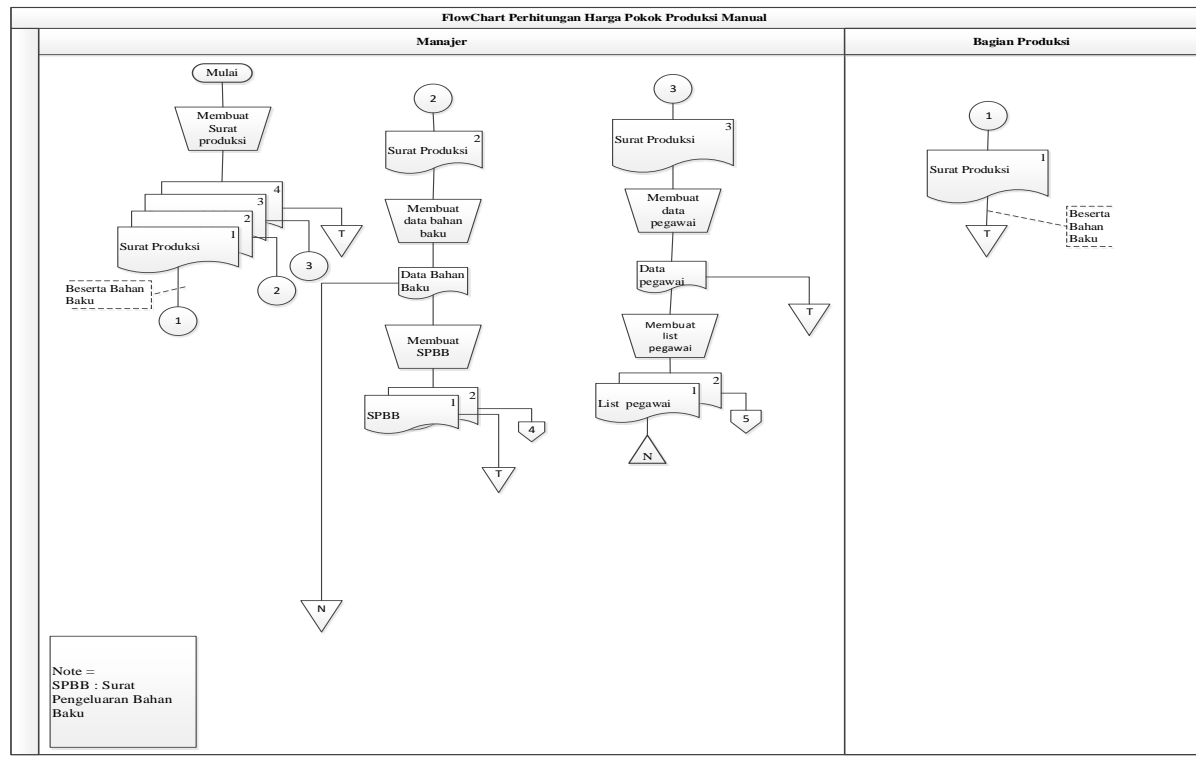

Gambar 1. Flowchart Prosedur Perhitungan Harga Pokok Produksi pada UD. Monas Bakery

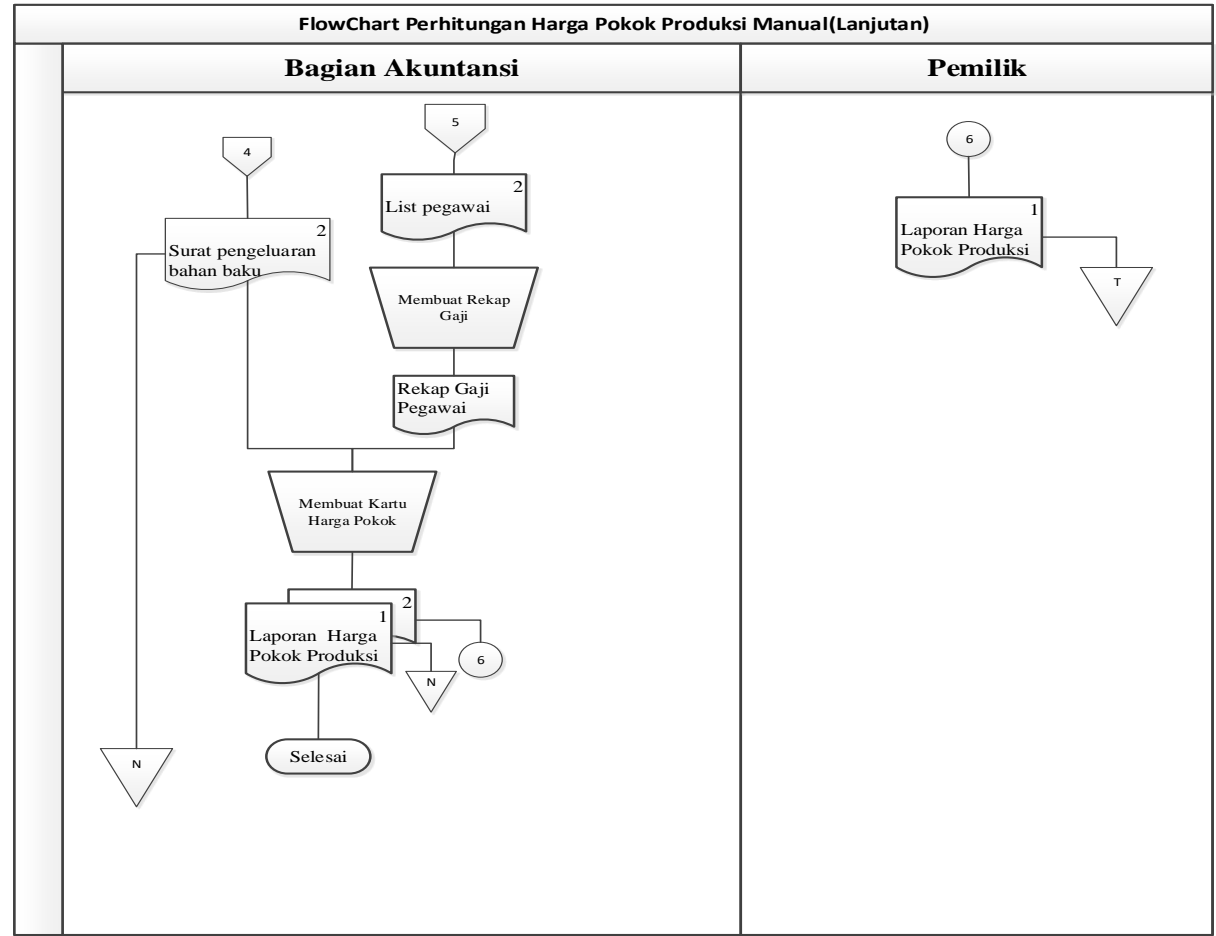

Gambar 2. Flowchart Prosedur Perhitungan Harga Pokok Produksi pada UD. Monas Bakery (lanjutan)

Analisa Perbandingan Perhitungan Harga Pokok Produksi Metode Full Costing dengan Variable Costing dalam Menentukan Harga Jual (Studi Kasus : UD. Monas Bakery)-( Lena Magdalena, Suwandi, 


\subsection{Flowmap Usulan Aplikasi Sistem Analisa Perbandingan Perhitungan Harga Pokok Produksi Metode Full Costing dan Variable Costing dalam menentukan harga jual pada UD Monas Bakery}

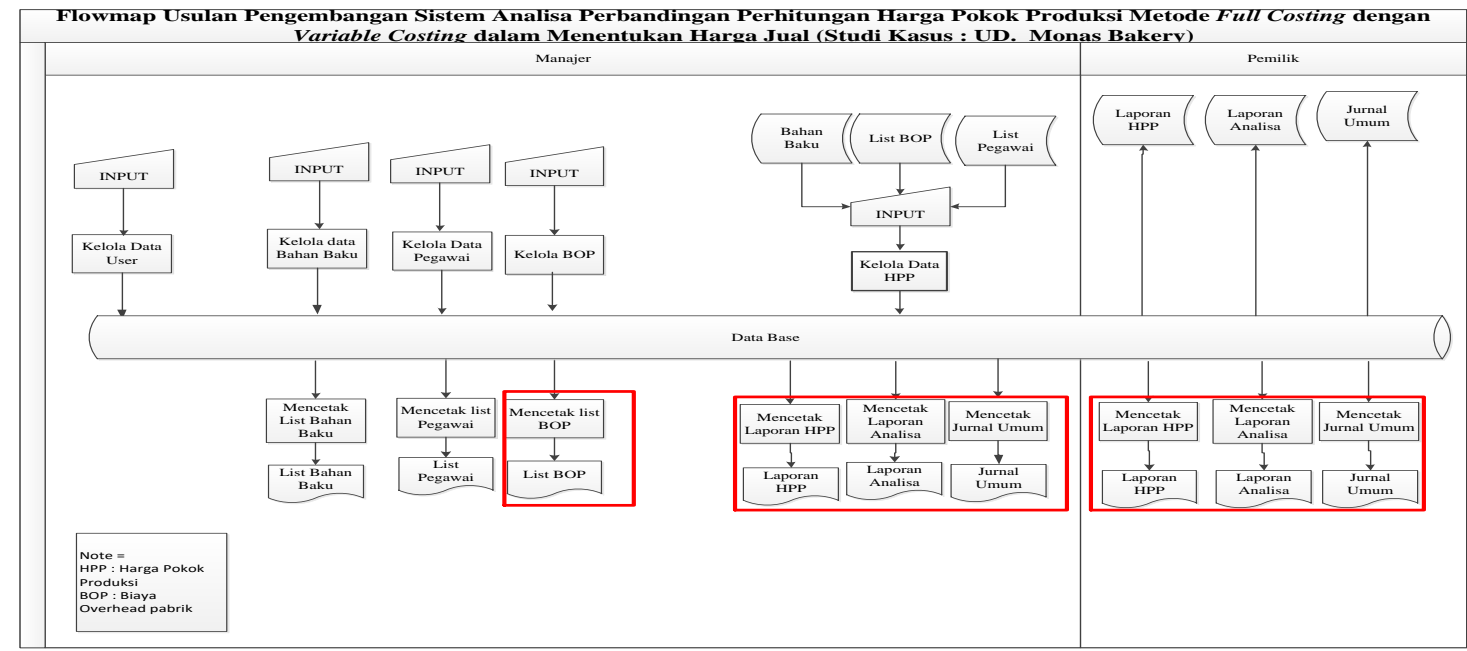

Gambar 3. Flowchart Prosedur Perhitungan Harga Pokok Produksi pada UD. Monas Bakery (lanjutan)

\section{4. $\quad$ Flowmap Usulan 3.6. Diagram Konteks (Context Diagram)}

Dalam sebuah sistem akuntansi, diagram konteks merupakan gambaran prosedur secara global yang menjelaskan tentang aliran input, proses dan output data-data yang diolah, diagram konteks untuk sistem akuntansi biaya produksi harga pokok produksi dapat dilihat pada gambar 8 di bawah ini :

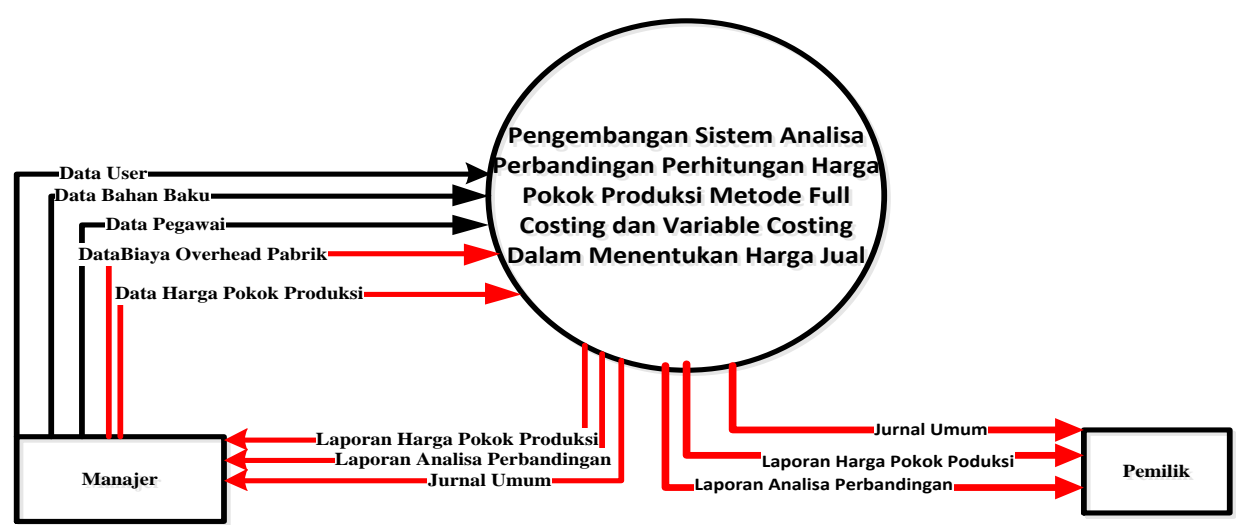

Gambar 4. Diagram Konteks Pengembangan Sistem Analisa perbandingan perhitungan harga pokok produksi metode full costing dengan varible costing dalam menentukan harga jual.

\subsection{Diagram Aliran Data (Data Flow Diagram/DFD) Level-0}

Dalam proses analisis sistem, DFD Level-0 merupakan tahap yang menggambarkan lebih rinci proses pengelolaan suatu data mulai dari data inputan, database yang digunakan sampai output yang

Analisa Perbandingan Perhitungan Harga Pokok Produksi Metode Full Costing dengan Variable Costing dalam Menentukan Harga Jual (Studi Kasus : UD. Monas Bakery)-( Lena Magdalena, Suwandi, 
dihasilkan atas pengelolaan data tersebut. Dasar dari pembuatan DFD level-0 ini yaitu Diagram Konteks. Diagram Aliran Data untuk sistem akuntansi biaya produksi harga pokok produksi dapat dilihat pada gambar 9 di bawah ini :

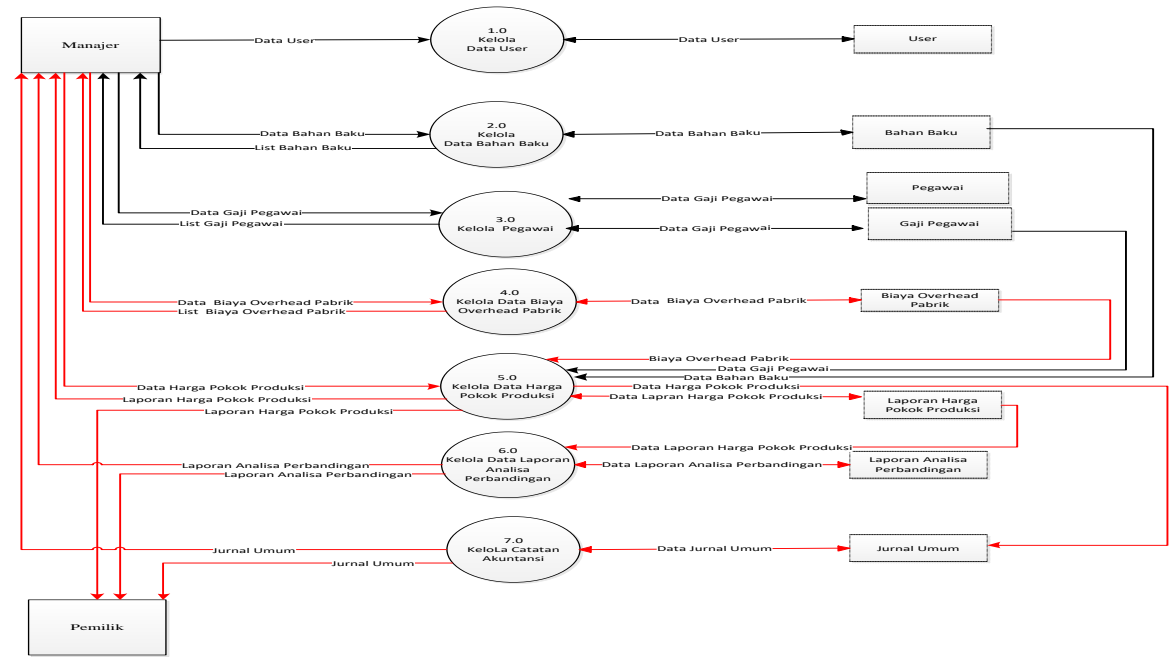

Gambar 5. DFD Level-0 Pengembangan sistem analisa perbandingan perhitungan harga pokok produksi metode full costing dengan varible costing dalam menentukan harga jual

\subsection{Entity Relationship Diagran (ERD)}

Entity relationship diagram memiliki fungsi memberikan gambaran hubungan antar entitas pada sebuah sistem. Adapun rancangan ERD dapat dilihat pada gambar 10 :

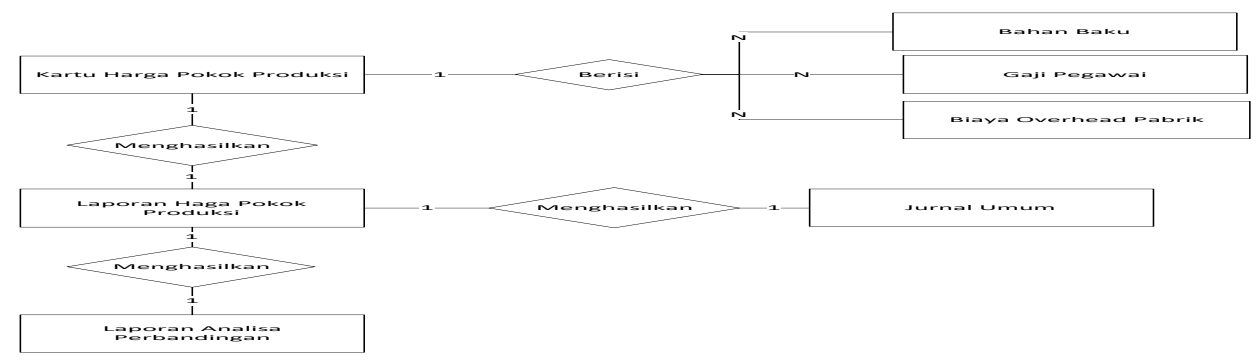

Gambar 6.Entity Relationship Diagram

Analisa Perbandingan Perhitungan Harga Pokok Produksi Metode Full Costing dengan Variable Costing dalam Menentukan Harga Jual (Studi Kasus : UD. Monas Bakery)-( Lena Magdalena, Suwandi, 


\section{IMPLEMENTASI SISTEM}

\subsection{Form Login}

Form login pada gambar 11 merupakan form awal yang tampil dalam aplikasi. Form login harus diisi oleh nama pengguna dan kata sandi. Pada Form Login bisa di akses oleh Manajer, Bagian akuntansi, dan Pemilik.

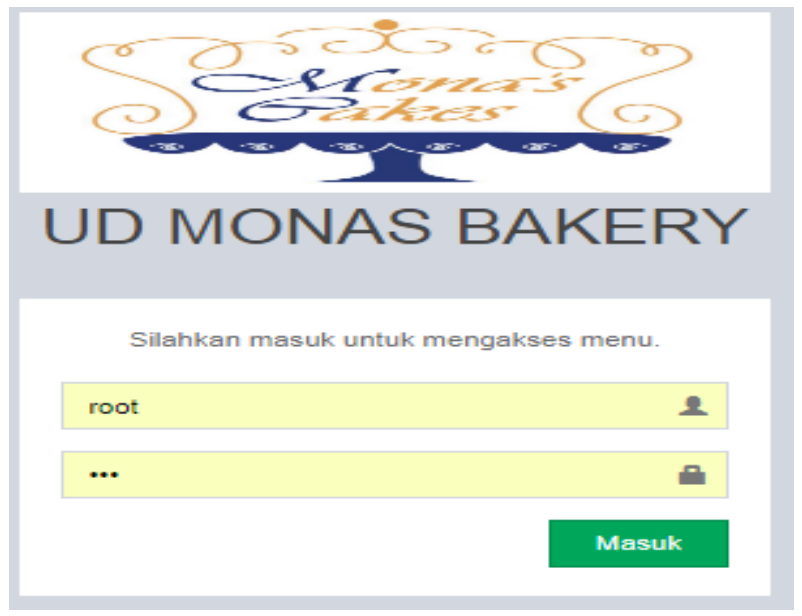

Gambar 7. Form Login

\subsection{Form Menu Utama Manajer}

Pada Form menu utama manajer, manajer dapat mengakses bahan baku, surat produksi, surat pengeluaran bahan baku, data pegawai, list pegawai dan biaya overhead pabrik.

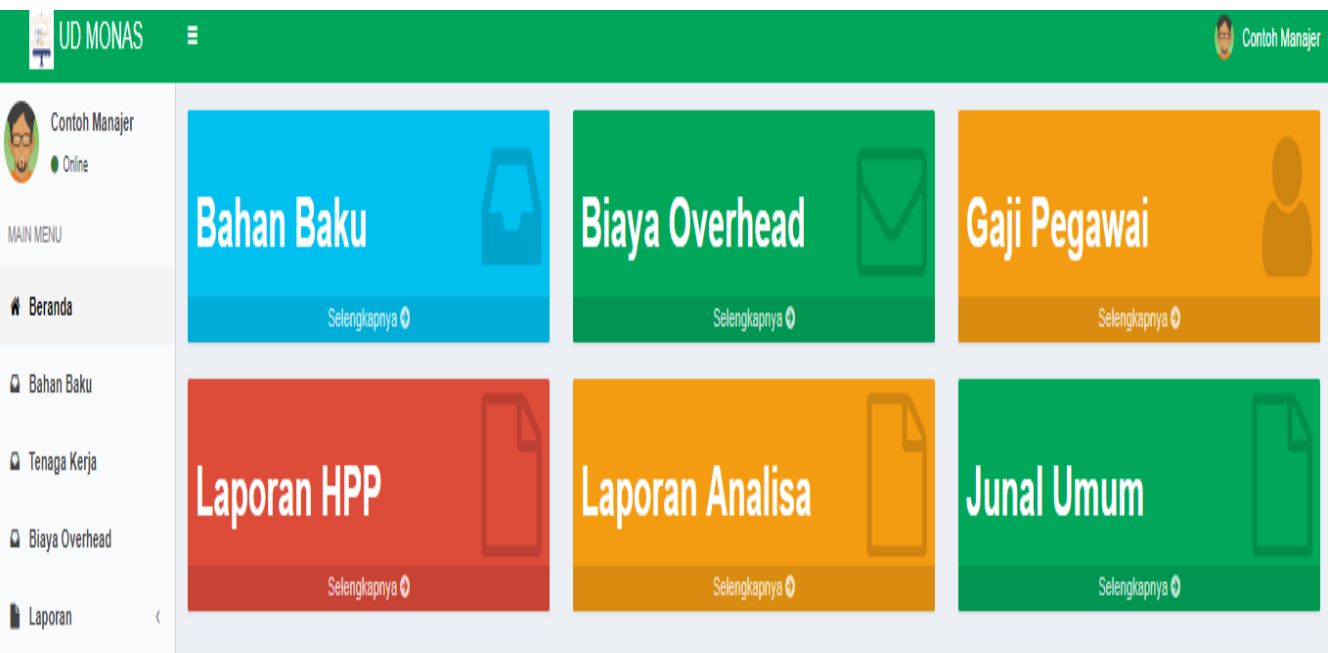

Gambar 8. Form Menu Utama Manajer 


\subsection{Form Laporan Harga Pokok Produksi}

Laporan Harga Pokok Produksi merupakan laporan yang berisi data yang berkaitan dengan produksi yang dilakukan dengan menggunakan dua metode. Pada gambar 13. terdapat tampilan Cetakan Laporan Harga Pokok Produksi.

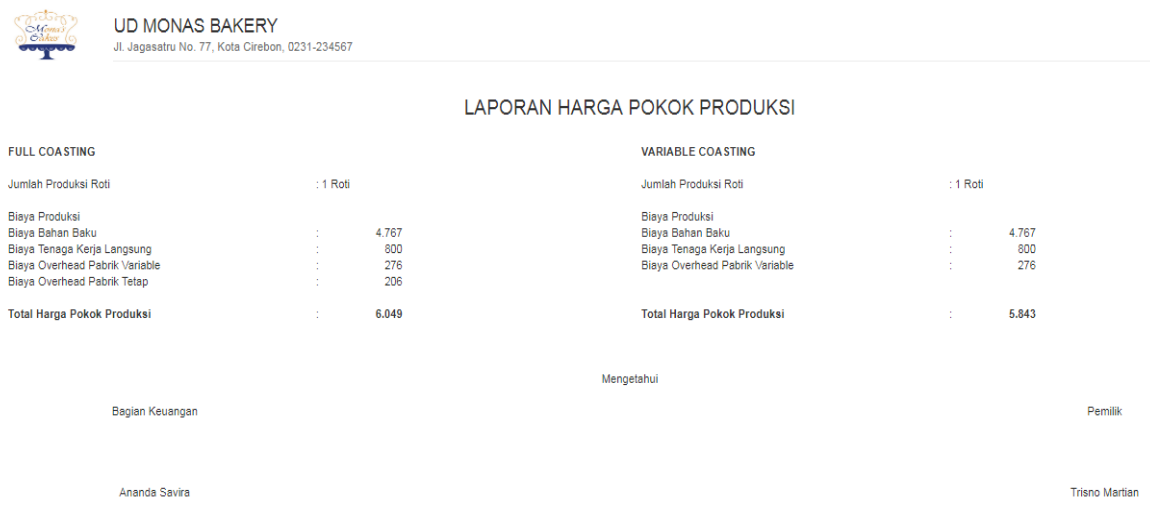

\section{Gambar 9. Laporan Harga Pokok Produksi}

\subsection{Form Laporan Analisa Perbandingan}

Laporan analisa perbandingan berisi perbandingan hasil perhitungan harga pokok produksi terhadap 2 metode. Pada gambar 12 terdapat tampilan Cetakan Laporan Analisa Perbandingan.

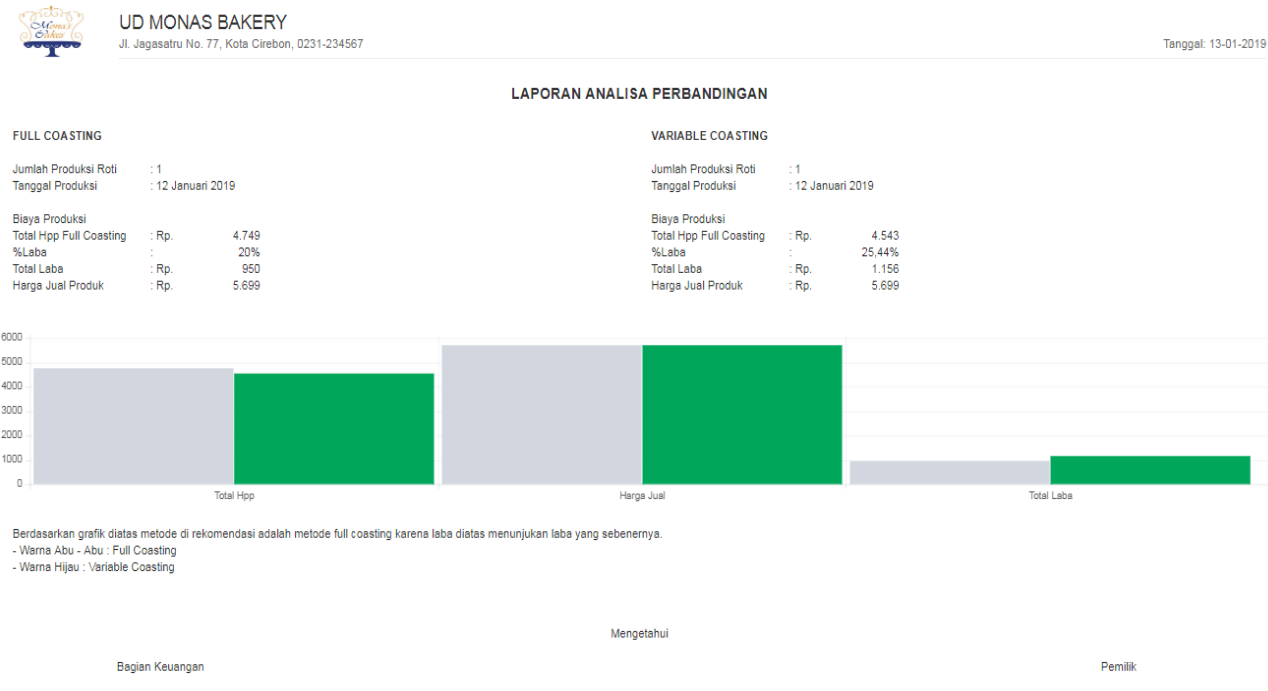

Gambar 10. Form Laporan Analisa Perbandingan 


\section{KESIMPULAN DAN SARAN}

\subsection{Kesimpulan}

Berdasarkan hasil observasi data dari UD Monas Bakery serta pembahasan dari bab sebelumnya mengenai aplikasi sistem harga pokok produksi, maka penyusun dapat memberikan kesimpulan yaitu :

1. Dengan adanya aplikasi perhitungan harga pokok produksi UD Monas Bakery dapat mengetahui secara detail komponen-komponen perhitungan harga pokok produksi yang sebenarnya serta harga jual roti pada satu kali produksi.

2. Komponen perhitungan harga pokok produksi dengan Metode full costing adalah: biaya bahan baku, biaya overhead pabrik, biaya tenaga kerja, biaya overhead pabrik tetap, biaya overhead pabrik variable.

3. Komponen perhitungan harga pokok produksi dengan metode variable costing adalah: biaya bahan baku, biaya overhead pabrik, biaya tenaga kerja, biaya overhead pabrik variable.

4. Harga pokok produksi menggunakan metode full costing lebih tinggi dibandingkan dengan variable costing.

5. Aplikasi ini dapat menghasilkan Laporan Harga Pokok Produksi secara komputerisasi,dan dapat mengetahui perbandingan harga pokok produksi menggunakan metode full costing dan variable costing.

\subsection{Saran}

Berdasarkan hasil observasi, perancangan dan pembuatan Aplikasi Pencatatan Harga Pokok Produksi di UD Monas Bakery Cirebon, beberapa usulan untuk pengembangan sistem komputerisasi ke depannya, antara lain :

1. Perlu diadakannya pengembangan sistem untuk jenis-jenis roti yang lainya, sehingga dapat dianalisa perhitungan harga pokok produksinya.

2. Sebaiknya aplikasi ini dapat membuat laporan keuangan seperti laporan rugi laba,buku besar untuk kebutuhan manajemen UD.Monas Bakery.

3. Perlu diadakan pengembangan sistem pengendalian internal yang lebih transparan.

\section{DAFTAR PUSTAKA}

[1] Dr. La Midjan. 2015. Sistem Informasi Akuntansi. Bandung :Lingga Jaya.

[2] HM,Jugianto.1999. "Analisis dan Desain Sistem Informasi. Yogyakarta: ANDI Yogyakarta

[3] Krismiaji. 2015. Sistem Informasi Akuntansi Edisi keempat.Yogyakarta :UPP STIM YKPN.

[4] Kusrini. 2007. Strategi Perancangan dan Pengolahan Bisnis Data. Yogyakarta: Andi Offset.

[5] Mulyadi. 1993. Akuntansi Biaya Edisi 5: Yogyakarta :STIE YKPN.

[6] Mulyadi. 2009. Akuntansi Biaya: Yogyakarta :STIE YPKPN.

[7] Mulyadi. 2016. Sistem Akuntansi. Jakarta: Selemba Empat

[8] Mursyidi. 2008 Akutansi Biaya. Bandung: Refika Aditama. 
